\title{
The Impeachment Exception to the Exclusionary Rules
}

Recently, there has been a pronounced expansion of the underlying rationale and the coverage of the rules excluding from criminal trials highly probative evidence obtained in violation of the accused's constitutional rights. ${ }^{1}$ For example, in Miranda $v$. Arizona ${ }^{2}$ and Escobedo v. Illinois ${ }^{3}$ the Court held that pretrial statements, even if voluntary, ${ }^{4}$ are inadmissible unless the defendant was properly warned of his rights to remain silent and to have the aid of counsel. ${ }^{5}$ Modifying this trend, however, is a line of cases generated by the Supreme Court's 1954 decision in Walder $v$. United States, ${ }^{6}$ which limits the operation of the exclusionary rules to the prosecution's effort to establish guilt. ${ }^{7}$

1 The first of these rules appeared in Weeks v. United States, 232 U.S. 383 (1914) (evidence obtained from an unlawful search and seizure by federal officials is inadmissible in a federal court). The scope of this rule has itself been greatly expanded. In 1948 the Weeks rule was held not to apply to the states. Wolf v. Colorado, 338 U.S. 25 (1949). It was seen principally as a judicially created rule of evidence designed to deter unlawful police action. $I d$. at 39 (Black, J., concurring). Today as a result of Mapp v. Ohio, 367 U.S. 643 (1961), the same rule does apply to the states and is "no mere rule of evidence, but part and parcel of the Constitution." Traynor, Mapp. v. Ohio At Large in the Fifty States, 1962 Duke L.J. 319, 339. See also Allen, Federalism and the Fourth Amendment, 1961 Sup. Cr. REv. 1, 24-26. But see Linkletter v. Walker, 381 U.S. 618 (1965). It is no longer designed solely to deter unlawful police action, but now protects the very integrity of our judicial system. Mr. Justice Clark observed in Mapp: "The criminal goes free if he must, but it is the law which sets him free. Nothing can destroy a government more quickly than its failure to observe its own laws, or worse, its disregard of the charter of its own existence." 367 U.S. at 659 .

2384 U.S. 436 (1966).

3378 U.S. 478 (1964).

4 Prior to Miranda and Escobedo, the Court used a voluntariness test. Bram v. United States, 168 U.S. 532 (1897). Bram was applied to the states in Brown v. Mississippi, 297 U.S. 278 (1935); cf. Rochin v. California, 342 U.S. 165, 173 (1952). But see Irvine v. California, 347 U.S. 128 (1954).

6 The Court said in Miranda: "Prior to any questioning, the person must be warned that he has a right to remain silent, that any statement he does make may be used as evidence against him, and that he has a right to the presence of an attorney, either retained or appointed. The defendant may waive effectuation of these rights, provided the waiver is made voluntarily, knowingly, and intelligently." Miranda v. Arizona, 384 U.S. 436, 444 (1966).

6347 U.S. 62 (1954).

7 See, e.g., United States v. Curry, 358 F.2d 904 (2d Gir. 1966); United States v. Grosso, 358 F.2d 154 (3d Cir. 1966); Tate v. United States, 283 F.2d 377 (D.C. Cir. 1960); State v. McClung, 66 Wash. 2d 654, 404 P.2d 460 (1965); cf. State v. Odom, 353 S.W.2d 708 (Mo. 1962). Contra, State v. Brewton, 422 P.2d 581 (Ore. 1967). 
Thus, unlawfully obtained evidence can still be used for the limited purpose of impeaching a defendant's testimony given on direct examination. ${ }^{8}$

In Walder, a previous narcotics indictment had been dismissed after the defendant had secured suppression of a heroin capsule obtained through an unlawful search and seizure. During his trial on a second narcotics offense committed two years later, the defendant voluntarily took the stand and made a sweeping denial that he had ever had narcotics in his possession. The prosecution was then permitted to introduce the evidence obtained from the earlier search and seizure solely to impeach the defendant's credibility, the jury being so instructed. Since 1954 the state and lower federal courts have extended this impeachment exception in two principal ways: the impeaching evidence may now be directly related to the offense being tried; ${ }^{9}$ the evidence may be a pretrial statement obtained from the defendant in violation of either the fifth or sixth amendment, in addition to a physical object obtained in violation of the fourth amendment as in Walder..$^{10}$

This comment focuses on the first of these extensions, since situations in which the evidence is directly related to the crime charged will undoubtedly occur much more often than the unique one in Walder where two prosecutions were involved.11 Nevertheless, some discussion of the

8 The rule established in Walder was contrasted with the Court's earlier decision in Agnello v. United States, 269 U.S. 20 (1925), which struck down an attempt to use illegal evidence to impeach a statement elicited from the defendant on cross-examination. Walder v. United States, 347 U.S. 62, 66 (1954).

9 See, e.g., United States v. Curry, 358 F.2d 904, 909-12 (2d Cir. 1966) (defendant's prior statement used to impeach his testimony that he had not worn a false moustache on the day of alleged theft); United States v. Grosso, 358 F.2d 154 (3d Cir. 1966) (two "black books" containing evidence of a numbers lottery obtained during an unlawful search and seizure used to impeach the testimony of a defendant convicted of a violation of the Gambling Tax Act that he had not been connected with such a lottery); Tate v. United States, 283 F.2d 377, 378-80 (D.C. Cir. 1960) (defendant's prior statement that he had come to the scene of the alleged theft with an alleged accomplice used to impeach his testimony that he had come alone and did not know the other person); State v. McClung, 66 Wash. 2d 654, 66263, 404 P.2d 460, 464 (1965) (defendant's prior statement that he had placed narcotics in the trunk of a car and knew who had committed the robbery used to impeach his testimony that he knew nothing of the robbery, the drugs, or how they happened to be in the car); cf. State v. Odom, 353 S.W.2d 708, 710-11 (Mo. 1962) (results of unlawful stomach pumping admitted after the defendant had testified as to the occurrence of the pumping but had not mentioned the results). These cases made another extension of Walder in that they did not require that the defendant's denial be sweeping in nature but rather allowed him to be impeached when his entire testimony was at least circumstantially related to the crime charged. Contra, State v. Brewton, 422 P.2d 581 (Ore. 1967) (no portion of the defendant's pretrial confession allowed to be used for impeachment purposes by the prosecution).

10 See cases cited note 9 supra.

11 See, e.g., United States v. Curry, 358 F.2d 904 (2d. Cir. 1966). The Second Circuit should never have reached the impeachment question because it overruled the trial judge's 
doctrine as applied in Walder is necessary to cover all the situations in which unlawfully obtained evidence might be used for impeachment purposes. Finally, in relation to the second extension, there is reason to believe, as the Oregon Supreme Court has already held, ${ }^{12}$ that the Supreme Court's decisions in Miranda and Escobedo have already overruled use of illegally obtained pretrial statements for impeachment purposes.

\section{I}

The extension to the Walder exception, which permits unlawfully obtained evidence directly related to the offense charged to be used for impeachment purposes, is dubious on three grounds: (1) it violates the requirements of Walder itself; (2) it could gradually defeat the major policy of deterring unlawful police action; and (3) it may tend to discourage defendants from testifying. ${ }^{13}$

The Supreme Court's holding in Walder seemed to be strongly influenced by the fact that the impeaching evidence did not bear directly on the charge in the second trial, and thus could not have influenced the jury on the question of guilt. ${ }^{14}$ Though in the opinion this consideration is not phrased explicitly in terms of prejudice on the question of

determination that the defendant's pretrial statement was obtained in violation of his constitutional rights and thus, in effect, said the evidence was admissible directly. However, the major part of the decision treated the evidence as if it were obtained unlawfully. See also United States v. Grosso, 358 F.2d 154 (3d. Cir. 1966); Tate v. United States, 283 F.2d 377 (D.C. Cir. 1960). The statement admitted to impeach the defendant in Tate had not been excluded from the prosecution's case in chief on a constitutional basis but rather because it violated the $M c N a b b$-Mallory rule against unlawful delays prior to arraignment. Mallory v. United States, 354 U.S. 449 (1957); McNabb v. United States, 318 U.S. 332 (1943). However, later decisions of the District of Columbia Circuit have not taken up this distinction. Inge v. United States, 356 F.2d 345 (D.C. Cir. 1966); White v. United States, 349 F.2d 965 (D.C. Cir 1965); Johnson v. United States, 344 F.2d 163 (D.C. Cir. 1964); Brown v. United States, 338 F.2d 543 (D.C. Cir. 1964). In any case, the Tate decision will be discussed as if it involved the violation of a constitutional right, as it appears safe to assume that cases involving violations of the $M c N a b b$-Mallory rule will also involve these rights. See also State v. Mcclung, 66 Wash. 2d 654, 404 P.2d 460 (1965); cf. State v. Odom, 353 S.W.2d 708 (Mo. 1962). Contra, State v. Brewton, 422 P.2d 581 (Ore. 1967).

12 State v. Brewton, 422 P.2d 581 (Ore. 1967).

13 Several lower court cases seem already to have indicated the demise of the extensions to the Walder rule. See, e.g., State v. Brewton, 422 P.2d 581 (Ore. 1967); Inge v. United States, 356 F.2d 345 (D.C Cir. 1966); White v. United States, 349 F.2d 965 (D.C. Cir. 1965); Johnson v. United States, 344 F.2d 163 (D.C. Cir. 1964); Brown v. United States, 338 F.2d 543 (D.C. Cir. 1964).

14 It is generally conceded, even by those favoring the exception, that prejudice would result to the defendant on the question of guilt despite the limiting instruction when the evidence is related to the crime charged. See, e.g., 42 Gro. L.J. 563, 565 (1954). The belief that the jury is probably unable to limit its use of highly prejudicial evidence appears throughout the law of evidence. See, e.g., Mr. Justice Cardozo's opinion in Shephard v. United States, 290 U.S. 96 (1933). 
guilt, it apparently is the basis for the Court's statement that the defendant "must be free to deny all the elements of the case against him without thereby giving leave to the Government to introduce by way of rebuttal, evidence illegally secured by it, and thereby not available for its case in chief." 15 Most courts that have extended the Walder doctrine correctly recognized this phrase as an obstacle to their decisions. In order to hurdle that barrier, they have characterized the admitted evidence as relating to "collateral matters," 16 "peripheral non-inculpatory matter,"17 or "lawful proper acts"18 not involving actual elements of the crime charged. The interpretation these cases impose on the phrase "elements of his crime" appears, however, to be much narrower than that suggested by the Court in Walder. The rationale for the establishment of this requirement-avoidance of prejudice to the defendant on the question of guilt-clearly is defeated when the unlawfully obtained evidence is as relevant to the charge being tried as that sought to be admitted, for example, in Tate $v$. United States. ${ }^{19}$ There, the defendant's case was almost certainly prejudiced by the introduction of his previous statement that he had come to the scene of the crime with the man the police caught stealing a typwriter, even though the jury had been instructed to use this evidence for impeachment purposes only. ${ }^{20}$

The Oregon Supreme Court recently stated that it was unable to follow the Tate holding that a defendant could be impeached when he testified on collateral matters as distinguished from simply denying his part in the crime. ${ }^{21}$ It called such a distinction "virtually unworkable,"

15 Walder v. United States, 347 U.S. 62, 65 (1954). The importance of this consideration was explicitly recognized in Johnson v. United States, 344 F.2d 163 (D.C. Cir. 1964), where the Court refused to admit a complete confession: "[E]vidence used purportedly to impeach [Johnson] . . . was a confession of the very charge on trial, raising a clear likelihood of prejudice not present when, as in Walder, the impeaching evidence is unrelated to the indictment. Thus, the Walder exception does not allow the testimony regarding Johnson's confession. . . . To permit the Government to introduce illegally obtained statements which bear directly on a defendant's guilt or innocence in the name of 'impeachment' would seriously jeopardize the important substantive policies and functions underlying the established exclusionary rules." $I d$. at 166. Accord, Brown v. United States 338 F.2d 453 (D.C. Cir. 1964).

16 See, e.g., United States v. Curry, 358 F.2d 904, 911 (2d Cir. 1966); Tate v. United States, 283 F.2d 377, 381 (D.C. Cir. 1960). But see State v. Brewton, 422 P.2d 581, 583 (Ore. 1967). See text accompanying note 23 infra.

17 Tate v. United States, 283 F.2d 377, 382 (D.C. Cir. 1960).

$18 \mathrm{Id}$. at 380. In United States v. Grosso, 358 F.2d 154, 162-63 (3d Cir. 1966), and State v. Mcclung, 66 Wash. 2d 654, 662, 404 P.2d 460, 464 (1965), no such characterization was made. By implication, therefore, these courts extended the Walder doctrine to evidence that may have been related to elements of the crime charged. See fact situations note 9 supra.

19283 F.2d 377 (D.C. Cir. 1960). See note 9 supra.

20 See Note, Impeaching Evidence Not Inadmissible Under McNabb-Mallory Rule, 45 MiNn. L. REv. 669, 673-74 (1961).

21 State v. Brewton, 442 P.2d 581, 583 (Ore. 1967). 
because a defendant taking the stand to tell his version of a crime would almost inevitably testify as to what might be called "collateral matters." 22 Even the Circuit Court for the District of Columbia has limited its position in Tate by including elements of the defense in its interpretation of the phrase "elements of his crime." 23

Besides violating the requirements of Walder, this extension to the impeachment exception undermines the policy of deterring unlawful police action. ${ }^{24}$ Although the prosecution could not use unlawfully obtained evidence in its case in chief, such evidence would still be useful to it. By holding the evidence in reserve, it could place the defendant in a position where he could: (1) take the stand and tell the "whole story" knowing full well that the unlawfully obtained evidence would then be admitted; (2) just deny the crime without going into detail; or (3) not

22 Ibid.

23 Inge v. United States, 356 F.2d 345 (D.C. Cir. 1966). Although the court remanded on the issue of whether or not Rule 5(a) of the Federal Rules of Criminal Procedure had been violated, it did state that if the rule had been violated, the statements would not have been admissible under the Walder exception, since, even though they were not confessions of guilt as in Johnson, they were still inculpatory. See text accompanying note 14 supra. The statements used to impeach the defendant's three claims of self-defense were: (1) that the deceased had attacked him with a knife (his earlier statement was that the deceased did not have a knife); (2) that he did not remember cutting the deceased, and that if he did, he did so in the heat of passion (his prior statement was that he did remember cutting him); and (3) that he was injured during the fight (his prior statement had made no mention of this). Id. at 349-50.

In White v. United States, 349 F.2d 965 (D.C. Cir. I965), the same court held as one of three grounds for reversal that the defendant's pretrial statement had been unlawfully admitted to impeach him. At his trial the defendant testified that the deceased had come at him with his hand in his pocket. His prior statement did not mention this fact. What distinguished this case from Tate, according to the court, was that here the impeaching evidence was crucial to the defendant's main defense of self-defense. It explained that the defendant made no "sweeping claims" as in Walder, "nor was the use of the statement restricted to lawful acts" which are purely "collateral matters" to the issue at bar, as in Tate; but "rather the use of the statement here bore on the central issue of the case." $I d$. at 968.

In light of these cases it would appear that if Tate came before the District of Columbia Circuit again, the result would be different; the defendant's testimony was just as central to his defense as were the statements in Inge and White. (The defense in Tate consisted mainly of defendant's own testimony that he had come to the scene of the crime alone, that the stolen article was thrust into his arms, and that he was running-not to get awaybut to catch up to the person who had given him the article in order to return it. This testimony was impeached by his earlier statement that he knew the person he was chasing and indeed had come to the scene of the crime with him.) Tate v. United States, 283 F.2d 377, 378 (D.C. Cir. 1960). See also Johnson v. United States, 344 F.2d 163 (D.C. Cir. 1964); Brown v. United States, 338 F.2d 543 (D.C. Cir. 1964).

24 The importance of the deterrence argument has been repeatedly emphasized in the courts. See, e.g., Elkins v. United States, 364 U.S. 206, 217 (1960); People v. Cahan, 44 Cal. 2d 434, 446-50, 282 P.2d 905, 913-14 (1955). For the most quoted example of the other side of the argument, see People v. Defore, 242 N.Y. 13, 19-25; 150 N.E.2d 585, 587-89 (1927) (Cardozo, J.). 
take the stand at all. Since the impact on the jury of a weak denial or refusal to testify could be just as harmful to the defendant as the admission of the evidence, deterrence of unlawful police activity by the exclusionary rules is seriously weakened. ${ }^{25}$

Finally, as the Oregon Court recently stated: "[A]s commendable as it may be to prevent perjury, the price of such prevention could be to keep defendants off the stand entirely." ${ }^{26}$ This in turn could keep much important non-perjurious testimony from reaching the jury. Even though a defendant had such information, he probably still would choose not to present it out of fear that his testimony would allow the excluded evidence to then be admitted. Thus, the defendant's testimony would be lost to the jury even as to those matters about which he would tell the truth.

\section{II}

The use for impeachment of unlawfully obtained evidence not directly related to the offense being tried presents a much closer question. Nevertheless, the balance does seem to favor rejecting the exception even in this limited situation.

The major justification for maintaining the exception is to insure that perjury and mistaken testimony is impeached. ${ }^{27}$ Yet, the only measurable loss to the judicial system in banning the evidence altogether would occur where a guilty person was acquitted on the basis of his testimony. This occurrence would appear unlikely for two reasons. First, in many instances the police will have accumulated sufficient evidence to obtain a conviction notwithstanding the perjury. Second, there is no certainty that the perjured testimony would be accepted by a jury. The defendant in a criminal case is automatically "impeached" by the fact that he is an interested party; thus, the jury will usually be skeptical of his assertions, especially the more sweeping ones.

A second consideration urged in support of Walder-the one on which the Supreme Court seemed to place principal reliance ${ }^{28}$-is that

2545 MrNN. L. REv. 669, 677-78 (1961). The deterrence argument was greatly emphasized in the Oregon Supreme Court's recent decision not to extend Walder in State v. Brewton, 422 P.2d 581, 582 (Ore. 1967).

26 State v. Brewton, 422 P.2d 581, 583 (Ore. 1967). Contra, Tate v. United States, 283 F.2d 377, 381 (D.C. Cir. 1960).

27 This policy is not mentioned explicitly in Walder but is in Tate v. United States, 283 F.2d 377, 379. (D.C. Cir. 1960).

28 The Court said: "It is one thing to say that the Government cannot make an affirmative use of evidence unlawfully obtained. It is quite another to say that the defendant can turn the illegal method by which evidence in the Government's possession was obtained to his own advantage, and provide himself with a shield against contradiction of his un- 
by deliberately taking advantage of the prosecution's inability to use the unlawfully obtained evidence in order to make a denial both perjurious and unnecessarily broad, the defendant waives any right he has to object to the admission of this evidence. The Court in Walder drew support for this argument from its earlier decision in Michelson $v$. United States, ${ }^{29}$ where it had held that by presenting evidence of his good character, the defendant opened up the subject for the prosecution, who could then use any evidence it had to show his bad character. ${ }^{30}$

On the surface, the Walder and Michelson situations are analogous. In both, the interest to be served by admitting the prosecution's evidence is increased after the defendant has testified because continued exclusion would allow his testimony to go to the jury unchallenged; in both, the defendant appears undeserving of the court's protection after he has deliberately tried to turn the exclusionary rule to his own advantage. But in Michelson the original exclusion was based on a simple evidentiary rule designed to keep out evidence thought to be more prejudicial than probative. ${ }^{31}$ In Walder, on the other hand, constitutional rights were involved, presenting issues independent of the probative value of the evidence and the defendant's reprehensible behavior. Thus, accepting the Michelson parallel is mere question-begging because it avoids consideration of the policies that originally lay behind the exclusionary rules; no decision should be reached until these policies are considered.

Two major policies would be served by abandoning the Walder exception. The initial, and possibly still most important, is that of deterring illegal police behavior by excluding all evidence unlawfully obtained. ${ }^{32}$ Admittedly, the incentive to acquire evidence unlawfully

truths. Such an extension of the WVeeks doctrine would be a perversion of the Fourth Amendment.

"Take the present situation. Of his own accord, the defendant went beyond a mere denial of complicity in the crimes of which he was charged and made the sweeping claim that he had never dealt in or possessed any narcotics. Of course, the Constitution guarantees a defendant the fullest opportunity to meet the accusation against him. . . Beyond that, however, there is hardly justification for letting the defendant affirmatively resort to perjurious testimony in reliance on the Government's disability to challenge his credibility." Walder v. United States, 347 U.S. 62, 65 (1954).

29395 U.S. 469 (1948), cited in Walder v. United States, 347 U.S. 62, 65 n.34 (1954).

30 Michelson v. United States, 335 U.S. 469, 479 (1948). See MCCormICK, EvidENcE 337 (1954).

31335 U.S. at 479.

32 See notes 24-25 supra and accompanying text. The deterrence argument established in the search and seizure cases is also applicable to the rules of Miranda and Escobedo (see note 4 supra and accompanying text), and to Rochin v. California, 342 U.S. 165 (1952) (evidence obtained from a stomach pumping without consent held to so "shock the conscience" as to be a violation of the due process clause and thus be inadmissible in court). Cf. Irvine v. California, 347 U.S. 128 (1954) (Frankfurter, J., dissenting). 
would not be very great if it were admissible only in a case as unusual as Walder. Nevertheless, it could be argued that a complete prohibition against use of unlawfully obtained evidence is needed to remove all incentive for illegal police behavior. ${ }^{33}$ The announcement of an absolute rule may have psychological impact on the police, if nothing else.

The second consideration behind the exclusionary rules has been characterized by the Supreme Court as "the imperative of judicial integrity." 34 As one commentator recently stated,

[I]n a constitutional democracy of limited powers, a government agency has no authority over an individual except that which is conferred upon it by law; if such authority is exceeded, the fruits of such excess should not be recognized by any branch of government, especially that branch which has the foremost role in furthering the rule of law. The law sets limits to the state's exercise of power over the individual, and, regardless of mitigating circumstances, a substantial overstepping of those limits should not be legally cognizable. A court sworn to uphold and promote observance of the law cannot adequately perform its function if it ignores illegality in the enforcement of the law. ${ }^{35}$

The admission of illegally obtained evidence, even if limited to the Walder situation, would fly in the face of this policy; it would necessarily involve judicial sanctioning of unlawful police behavior. ${ }^{30}$

In reply, one could argue that by excluding the tainted evidence, the judges are thereby sanctioning perjury. However, Mr. Justice Brandeis has pointed out that "Our government is the potent omnipresent

33 See, e.g., Note, Standing to Object to an Unreasonable Search and Seizure, 34 U. CHI. L. REv. 342 (1967).

34 Elkins v. United States, 364 U.S. 206, 222 (1960). This policy is generally said to have originated in the dissents of Justices Holmes and Brandeis in Olmstead v. United States, 277 U.S. 438 (1928).

35 Schwartz, Retroactivity, Reliability and Due Process, 33 U. CHI. L. REv. 719, 751-52 (1966). See also People v. Reilly, 105 N.Y.S.2d 845 (Ct. Spec. Sess. 1951) (Oliver, J., concurring).

36 See 45 MINN. L. REv. 669, 679 (1961). An additional policy behind the exclusionary rules has been characterized as a "privilege against conviction by unlawfully obtained evidence." Allen, Federalism and the Fourth Amendment, 1961 SUP. CT. REv. 1, 35. The rationale behind it has been expressed as follows: "[J]ust as we cannot tolerate the continued imprisonment of a man whose conviction was based on unreliable evidence, so we cannot tolerate the continued imprisonment of a man whose conviction failed in other respects to meet the fundamental legal standards of the community." Schwartz, note 35 supra, at 749. To advance this policy as a basis for overruling Walder would be anomalous, however, because a defendant who has deliberately committed perjury seems hardly worthy of being afforded this privilege. Rather, arguments for overturning Walder should focus on policies that are independent of the behavior of the defendant. 
teacher .... . If the government becomes a lawbreaker, it breeds contempt for the law; it invites every man to become a law unto himself."st Thus, given the choice of whether it could do greater harm to "sanction" the individual or the governmental wrong, the answer is clearly the latter.

In balancing the desirability of insuring that perjury does not go unimpeached against maintaining absolute deterrence and governmental integrity, no clear cut conclusion appears. The gains on both sides are tenuous. Nevertheless, in light of what has been said about the slight effect impeachment of the defendant's testimony would have in most cases, ${ }^{38}$ deterrence and integrity appear to provide the more certain gain, and perhaps the more important as well. Furthermore, to keep the exception for just the limited situations where two prosecutions were involved and the defendant made an unnecessarily broad denial would burden the judicial system with the cost of administering a minor distinction in an area of law presently overburdened with such technicalities.

\section{III}

The second principal extension of the Walder exception has been its application to a defendant's pretrial statements. This would appear to be a natural extension in situations where the trial court is confident that the statements are as reliable as physical evidence normally is; ${ }^{39}$ the two types of evidence would then be equally capable of impeaching the defendant's testimony. ${ }^{40}$ The Supreme Court's recent decisions in Miranda v. Arizona ${ }^{41}$ and Escobedo v. Illinois ${ }^{42}$ seem to indicate, however, that this extension is no longer tenable. Before a suspect can make a statement admissible directly at his trial, he must have been effectively apprised of his rights to remain silent and to have the aid of counsel.43 It is contended here that, as the Oregon Supreme Court recently held, ${ }^{44}$

37 Olmstead v. United States, 277 U.S. 438, 485 (1928) (Brandeis, J., dissenting).

38 See text following note 27 supra.

39 United States v. Curry, 358 F.2d 904, 911 (2d Cir. 1966) stating that Tate v. United States, 283 F.2d 377 (D.C. Cir. 1960) extended the Walder doctrine to statements.

40 The distinction between physical evidence and statements is noted in 4 Hous. L. REv. 144 (1966), criticizing Curry v. United States, 358 F.2d 904 (2d Cir. 1966), and Note, supra note 20, 45 MINN L. REv. at 674-76 (1961), criticizing Tate v. United States, 283 F.2d 377 (D.C. Cir. 1960). A further distinction between the two is that while physical evidence could be absolute proof that perjury had been committed, a previous statement could only show that the defendant had contradicted himself.

$\$ 1384$ U.S. 436 (1966). See note 5 supra.

42378 U.S. 478 (1964).

43 Miranda v. Arizona, 384 U.S. 436, 444 (1966). See note 5, supra.

44 State v. Brewton, 422 P.2d 581 (Ore. 1967). See text accompanying notes 21-22 supra. 
the defendant's pretrial statements made in violation of this procedure have now been made unavailable to the prosecution for any purpose.

There are two possible ways to avoid this conclusion. First, it could be argued that Miranda and Escobedo were not based on a reliability rationale and hence were not meant to affect the impeachment rule as previously applied. Support for this argument can be found in Johnson v. New Jersey, ${ }^{45}$ where the Court stated that Miranda and Escobedo added little to the reliability of the guilt determining process.

To maintain this position is, however, to disregard what appears to be the best interpretation of the two decisions-that they are the Court's final effort to end judicial frustration caused by the clash between the inability to know what goes on at the police precinct and the desire to check "the danger [of secret interrogation] at the outset." 46 The method chosen was to try to avoid the questions of voluntariness and reliability by prescribing conditions for lawful police interrogation. Continued application of the Walder rule to pretrial statements will make it necessary for the courts to determine the reliability question in all cases where the prosecution takes advantage of the impeachment exception, thereby immersing the courts in the very task that Miranda and Escobedo were designed to obviate.

Furthermore, as one commentator has noted, ${ }^{47}$ the importance of the reliability rationale in these two cases should not be underestimated. The Court explicitly stated in Escobedo: "We have learned the lesson of history, ancient and modern, that a system of criminal law enforcement which comes to depend on the 'confession' will, in the long run be less reliable, and most subject to abuses . . .."48 Moreover, it must be remembered that the Johnson decision was concerned with the question of whether Miranda and Escobedo should be applied retroactively. Prior to Johnson, the Court had determined that the retroactivity question would turn principally on whether or not the newly established rule affected the reliability of the guilt-determining process. ${ }^{49}$ Thus,

45384 U.S. 719,730 (1966).

46 Kamisar, A Dissent From the Miranda Dissents: Some Comments on the "New" Fifth Amendment and the Old "Voluntariness" Test, 65 Mrch. L. REv. 59, 92 (1966).

47 "But even if the doctrine is no longer primarily based on a fear of untrustworthy confessions, the constitutional rules may still have an intended effect upon the reliability of the guilt-determining process. For as the Court pointed out in the opinion that most explicitly indicated that the exclusionary rule does not depend upon a specific determination of unreliability, 'confessions cruelly extorted may be and have been, to an unascertained extent, found to be untrustworthy." Mishkin, Foreword: The High Court, the Great Writ and the Due Process of Time and Law, 79 HARv. L. REv. 56, 84 (1965), quoting Rogers v. Richmond, 365 U.S. 534, 541 (1961).

48378 U.S. at 488-89 (emphasis added).

49 Linkletter v. Walker, 381 U.S. 618, 639 (1965). Accord, Tehen v. United States ex rel. Shott, 382 U.S. 406 (1965). See generally Mishkin, supra note 47. 
in Johnson the Court had to deemphasize the importance of the reliability rationale of Miranda in order to reach the negative result it seemed to desire for other reasons. ${ }^{50}$ Once taken out of this context, the reliability rationale seems to have sufficient vitality to warrant the much less serious step of dispensing with the Walder exception in regard to pretrial statements.

The conclusion that Miranda and Escobedo have implicitly overruled Walder with regard to pretrial statements can also be avoided by urging that these cases were meant to apply only to a confession of guilt and hence not to affect statements made on issues "collateral" to this question. ${ }^{51}$ This position, however, ignores the implication if not the explicit language of Miranda. There the Court said that the exclusion of pre-trial statements covered so-called exculpatory as well as inculpatory statements; ${ }^{52}$ the same conclusion would seem to follow as to statements on collateral issues. For the court reasoned that:

[S]tatements merely intended to be exculpatory by the defendant are often used to impeach his testimony at trial or to demonstrate untruths in the statement given under interrogation and thus to prove guilt by implication. These statements are incriminating in any meaningful sense of the word and may not be used without the full warnings and effective waiver required for any other statement. ${ }^{53}$

50 Throughout all the retroactivity decisions, the Court seems to be concerned with a much more practical problem than whether or not the guilt-determining process is undermined. For example, in Johnson it said; "[R]etroactive application of Escobedo and Miranda would seriously disrupt the administration of our criminal laws." Johnson v. New Jersey, 384 U.S. 719, 731 (1966). Perhaps the clearest expression of this concern is found in Linkletter, where the Court cautioned: "Finally, there are interests in the administration of justice and the integrity of the judicial process to consider. To make the rule of Mapp retrospective would tax the administration of justice to the utmost. Hearings would have to be held on the excludability of evidence long since destroyed, misplaced or deteriorated. If it is excluded, the witnesses available at the time of the original trial will not be available or if located their memory will be dimmed. To thus legitimate such an extraordinary procedural weapon that has no bearing on guilt would seriously disrupt the administration of justice." Linkletter v. Walker, 381 U.S. 618, 637-38 (1965). See also Tehan v. United States ex rel. Shott, 382 U.S. 406,418 (1966). That this is a key rationale behind the decisions is implied by several commentators. See, e.g., Note, Past Convictions Obtained Through Unreasonable Search and Seizure, 25 GA. B.J. 238, 239 (1962). This factor is also prominent in the arguments of those authors favoring nonretroactivity. See, e.g., Bender, The Retroactive Effect of an Overruling Constitutional Decision: Mapp v. Ohio, 110 U. PA. L. Rev. 650, 659 (1962); Traynor, supra note 1, at 34I-42. For a full scale attack on the retroactivity decisions as a whole and on the Mishkin article, supra note 47 , in particular, see Schwartz, supra note 35 .

51 The distinction between collateral as opposed to directly relevant evidence was made in United States v. Curry, 358 F.2d 904 (2d Cir. 1966); see text accompanying notes 16-18 supra.

52 Miranda v. Arizona, 384 U.S. 436, 476-77 (1966).

63 Id. at 477. 


\section{GoncLuSION}

The impeachment exception as defined in Walder represents a definite chink in the armor of the exclusionary rules. While it may justifiably be used to bring in physical evidence not directly related to the crime charged, Mirand $a$ and Escobedo indicate that any use of illegally obtained pre-trial statements will be prohibited. In any event, evidence directly related to the crime charged should not be permitted before the jury under the thin veil of impeachment. The possibility of improper prejudice to the merits of defendant's case, the deterrent effect on his willingness to testify, and the incentive provided to the police to act unlawfully are losses to the judicial system which greatly outweigh the possible gains from the unmasking of perjury. 